Scientific Note

\title{
New records of Pelecinus polyturator (Drury) (Hymenoptera: Proctotrupoidea: Pelecinidae) for Brazil
}

Nuevos registros de Pelecinus polyturator (Drury) (Hymenoptera:

Proctotrupoidea: Pelecinidae) para Brasil

Ana F. A. Sousa $^{1}$, Alexsandra C. Nascimento ${ }^{1}$, Marcelo T. Tavares ${ }^{2}$ \& $\&$

Daniell R. R. Fernandes ${ }^{1}$

${ }^{1}$ Instituto Nacional de Pesquisas da Amazônia, Coordenação de Biodiversidade, Av. André Araújo, 2936, Aleixo, 69067-375 Manaus, AM, Brazil.

${ }^{2}$ Universidade Federal do Espírito Santo, Departamento de Ciências Biológicas, Av. Fernando Ferrari, 514, Goiabeiras, 29075-910 Vitória, ES, Brazil.道daniellrrfernandes@gmail.com

\section{ZooBank: urn:lsid:zoobank.org:pub:A6D435EE-E3C1-4AEB-A2B1-CD2E990F41A8 https: / / doi.org/ 10.35249/rche.46.4.20.20}

\begin{abstract}
Species of Pelecinidae are very uncommonly collected in Brazil, despite they are one of the largest and most remarkable species of Hymenoptera. Here in, we report new records of Pelecinus polyturator (Drury, 1773) for Acre, Maranhão (Amazon rainforest) and Espírito Santo (Atlantic rainforest).
\end{abstract}

Key words: Amazon rainforest, Atlantic rainforest, Neotropical region.

Resumen. Las especies de Pelecinidae se recolectan con muy poca frecuencia en Brasil, apesar de que son una de las especies más grandes y notables de Hymenoptera. Aquí, reportamos nuevos registros de Pelecinus polyturator (Drury, 1773) para Acre, Maranhão (Selva Amazónica) y Espírito Santo (Selva Atlántica).

Palabras clave: Mata Atlântica, Región Neotropical, Selva Amazónica

Pelecinidae (Hymenoptera) is a peculiar group of New World parasitoid wasps and it assembles three extant species in the unique genus Pelecinus Latreille (Johnson \& Musetti 1999). Their females have slender and peculiar body shape, with 2.0 to 9.0 millimeters in length, and they are among the longest Hymenoptera. The metasomal segments are long, tubular, and their articulations allow rotation and ample vertical movement, an adaptation for searching and identifying hosts underground (Mason 1984). Fossil pelecinids (39 species in ten genera) were described from central and eastern Asia since Middle Jurassic (aprox. $165 \mathrm{Ma}$ ), and those females presented a similar elongated metasoma (Liu et al. 2009; Shih et al. 2009). Therefore, extant pelecinids species are relicts of a pattern of body shape to explore a specific host guild which evolved a long time ago. Hosts and aspects of natural history are known only to Pelecinus polyturator (Drury) (Hymenoptera: Proctotrupoidea: Pelecinidae) that seems to be a solitary koinobiont endoparasitoid of larvae to pupae of some Scarabaeidae beetles (Masner 2006). This wasp was recorded as parasitoid of

Received 13 November 2020 / Accepted 3 December 2020 / Published online 23 December 2020

Responsible Editor: José Mondaca E. 
Phyllophaga anxia (LeConte), P. inversa (Hornm), P. drakei Kirby, P. rugosa (Melsheimer) (Melolonthinae), and Podischnus agenor Olivier, all soil inhabitants (Lim et al. 1980; Johnson y Musetti 1999). In addition, the species are primarily thelytokous in areas north of Mexico, where males are restricted in distribution. In southern areas the species is bisexual (Brues 1928; Johnson \& Musetti 1999).

Pelecinus thoracicus Klug occurs in Mexico; P. dichrous Perty, in Brazil, Paraguay, Argentina and Uruguay; and P. polyturator, is widespread in America and has been reported from Canada, USA, Mexico, Guatemala, Honduras, Nicaragua, Costa Rica, Panama, Colombia, Venezuela, French Guiana, Ecuador, Brazil, Bolivia, Paraguay, Argentina, and Uruguay (Johnson \& Musetti 1999; Lara 2020). In Brazil, P. polyturator are recorded for the following states: Amazonas, Alagoas, Bahia, Goiás, Mato Grosso, Minas Gerais, Pará, Paraná, Pernambuco, Rio de Janeiro, Rio Grande do Sul, São Paulo and Santa Catarina (Lara 2020). Despite they are one of the largest and most remarkable species of Hymenoptera, species of Pelecinidae are rarely collected in some areas. The knowledge of the actual geographic distribution is fundamental to evaluate eventual threats to these relict species. So, we present new distributional records to $P$. polyturator intending to expand its actual distributional range.

This study was based on material deposited in the following four institutions (names of curators given in parenthesis):

IBCBE - Coleção de Insetos Entomófagos “Oscar Monte", Instituto Biológico, Campinas, São Paulo, Brazil (V.A. Costa).

INPA - Instituto Nacional de Pesquisas da Amazônia, Manaus, Amazonas, Brazil (M.L. Oliveira).

LRRP - Instituto Biológico, Ribeirão Preto, São Paulo, Brazil (N.W. Perioto).

UFES - Universidade Federal do Espírito Santo, Vitória, Espírito Santo, Brazil (M.T. Tavares).

The specimens were identified based on the key presented by Johnson \& Musetti (1999). Observations were carried out using a Leica MZ 9.5 stereomicroscope under fluorescent light source. Photographs were taken using a Leica (M165C) stereomicroscope with a DFC420 digital camera and Leica Application Suite V3.4.1 (Version 2009). Series of partially focused digital images were stacked using the Helicon Focus software (Version 6.7) to produce final images with enhanced quality.

Species distributions were assembled in a dataset and incorporated into distribution maps. Geographic coordinates of the species records, if not present in labels, were taken from Google Earth software (https://www.google.com/earth/), and the map was generated using SimpleMappr (Shorthouse 2010).

\section{Pelecinus polyturator (Drury, 1773)}

(Figs. 1A-1E)

Material examined. $39 \circ$ and $11 \delta^{\top}$. MEXICO. El Triunfo, Chiapas, $15^{\circ} 39^{\prime} 20 S 92^{\circ} 48^{\prime} 42^{\prime \prime} \mathrm{W}$, 2100 masl, 2001, P. Kowarile coll. (2ᄋ, 20, \#0150787-0150790, UFES). PANAMA. Chiriqui: Renacimiento, Santa Clara, 1,200 masl, 20-22.v.1977, B.C. Ratcliffe coll. (2ᄋ, 1§̂, INPA). BOLIVIA. Santa Cruz: Samaipata, 21-22.i.1989 (1, INPA). BRAZIL. Amazonas: Manaus, Campinas Biological Reserve, 3.iii.1977, N.D. Penny coll. (3 + , INPA); same locality, 1.ii.1975, N. Tangerini coll. (1, INPA); same locality, 14.i.1977 and 3.iii.1977, B.C. Ratcliffe coll. (4ㅇ, INPA); same locality, 14.i.1977, N.D. Penny coll. (8ㅇ, INPA); Manaus, Adolpho Ducke Forestry Reserve, 27.ii.1976, B. Mascarenhas coll. (1, INPA). Acre: Bujari, FES Antimary, 09²0'01"S 68¹9'17"W, 19.xi-3.xii.2016, Malaise trap, E.F. Morato \& J.A. Rafael cols, Rede

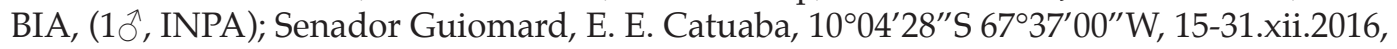


Malaise trap, E.F. Morato \& J.A. Rafael cols, Rede BIA, (1ðૂ, INPA). Maranhão: Carolina, Marajá Farm, $07^{\circ} 15^{\prime} 40^{\prime \prime} S$ 47 $22^{\prime} 48^{\prime \prime}$ W, 13.xii.2001, Malaise, F.L. Oliveira \& J. Vidal colls.

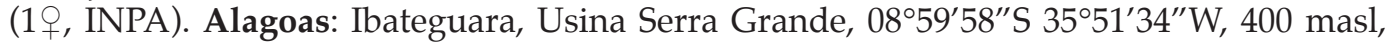
29.v.2007, J.A. Rafael \& F.F. Xavier Filho colls. (1ㅇ, INPA). Minas Gerais: Cambuquira, ii.1942, H.B. Lopes coll. (1ㅇ, INPA); Alto Caparaó, Caparaó National Park, 20³0’05”S 414'16"W, 1465 masl, 07-14.iii.2013, Malaise, C.O. Azevedo \& F.B. Fraga colls. (4우, \#0151784-0151787, UFES). Espírito Santo: Atílio Vivácqua, Serra das Torres, 2959'53"S 4112'42”W, 14.iv.2007, C. Waichert coll. (1ㅇ, \#0063078, UFES); Ibitirama, Caparaó National

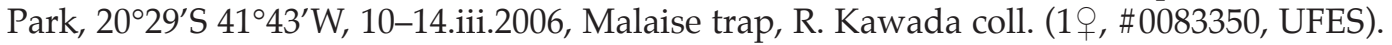
Rio de Janeiro: Teresópolis, Serra dos Orgãos National Park, 22²6'15.0"S 4256'15.0”W, 06-11.i.2005, Moericke trap, A.L.B.G. Peronti \& eq. colls. (1へ̃, \#0023497, UFES); same

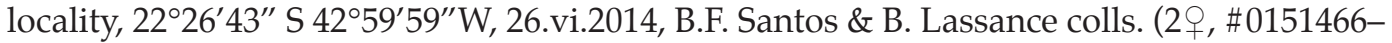
0151467, UFES). São Paulo: Campos do Jordão, ii.2005, L.B. Reis coll. (1+, \#0038482, UFES); Ribeirão Grande, Intervales State Park, Barra Grande, Anta trail, 10-13.xii.2000, Malaise trap, M.T. Tavares \& eq. colls. (1 $\delta^{\Uparrow}$, \#0038481, UFES); São Carlos, Fazenda Canchim, 2.ii.1991, Moericke trap, M.T. Tavares coll. (1ठ̋, \#0038441, UFES); São Roque, Alto da Serra,

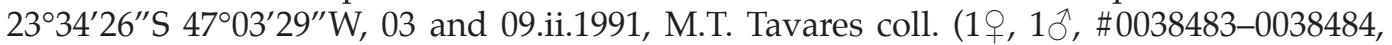

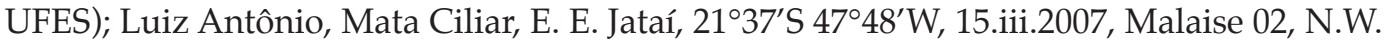
Perioto e eq. (1つ̄, LRRP). Paraná: Colombo, EMBRAPA, 23.iii.1987 (1ㅇ, \#0038478, UFES); Ponta Grossa, Vila Velha, IAPAR Reserve, 02.v.1988 (1+, \#0038480, UFES); Telêmaco Borba, Samuel Klabin Reserve, 13.iv.1987 (1요 \#0038479, UFES); Ponta Grossa, 2505'42”S 5009'43”'W, Phaseolus vulgaris L., 01.i.2002, B. Alleoni leg. (1ㅇ, IBCBE). Rio Grande do Sul: Cascata, 10-18.i.2019, Nava D.E. \& Scheunemann T. (10̄, INPA).

Geographical records. Here in, we provide new records for Acre, Maranhão (Amazon rainforest) and Espírito Santo (Atlantic rainforest) (Fig. 1E).

Remarks. Some females analyzed show different size and color pattern (mainly in the hindwings) (Figs. 1A, 1B, 1C). Variation like those was mentioned by Johnson \& Musetti (1999), who verified that they are intraspecific. Although the material analyzed comes from entomological collections, which receive deposits of a large volume of specimens of insects from different projects, few specimens are present in these collections (01 IBCBE, 26 INPA, 01 LRRP and 21 UFES). According to Lara \& Perioto (2014), for a more robust sampling, long-term studies and successive sampling can be an effective strategy to collect $P$. polyturator. With Malaise traps surveys, some long-term sampling in the same sampling area proved to be effective for capturing uncommon Hymenoptera families, such as Chrysididae, Dryinidae, Monomachidae and Sclerogibbidae (Lucena et al. 2012; Versuti et al. 2014; Perioto et al. 2016; Fernandes et al. 2017).

\section{Acknowledgments}

We thank Coordenação de Aperfeiçoamento de Pessoal de Nível Superior (CAPES)/ Programa Nacional de Pós Doutorado (PNPD) for postdoctoral fellowship to D.R.R.F.; Programa de Capacitação Institucional - PCI/CNPq (process no 312879/2019-9); Fundação de Amparo à Pesquisa do Estado do Amazonas (FAPEAM) Edital Nº 030/2013 - Universal Amazonas (process n ${ }^{\circ}$ 062.00770/2015); Rede Bionorte: Biodiversidade de insetos na Amazônia (process n ${ }^{\circ} 407627$ / 2013-8) and Fundação de Amparo à Pesquisa e Inovação do Espírito Santo (FAPES) (process n 67658830/2014). Conselho Nacional de Desenvolvimento Científico e Tecnológico (CNPq) for PPGENT/INPA master's fellowship to A.C.N. Invertebrate Collection of Instituto Nacional de Pesquisas da Amazônia - INPA for allowing the use of photographic equipment used in this work. 

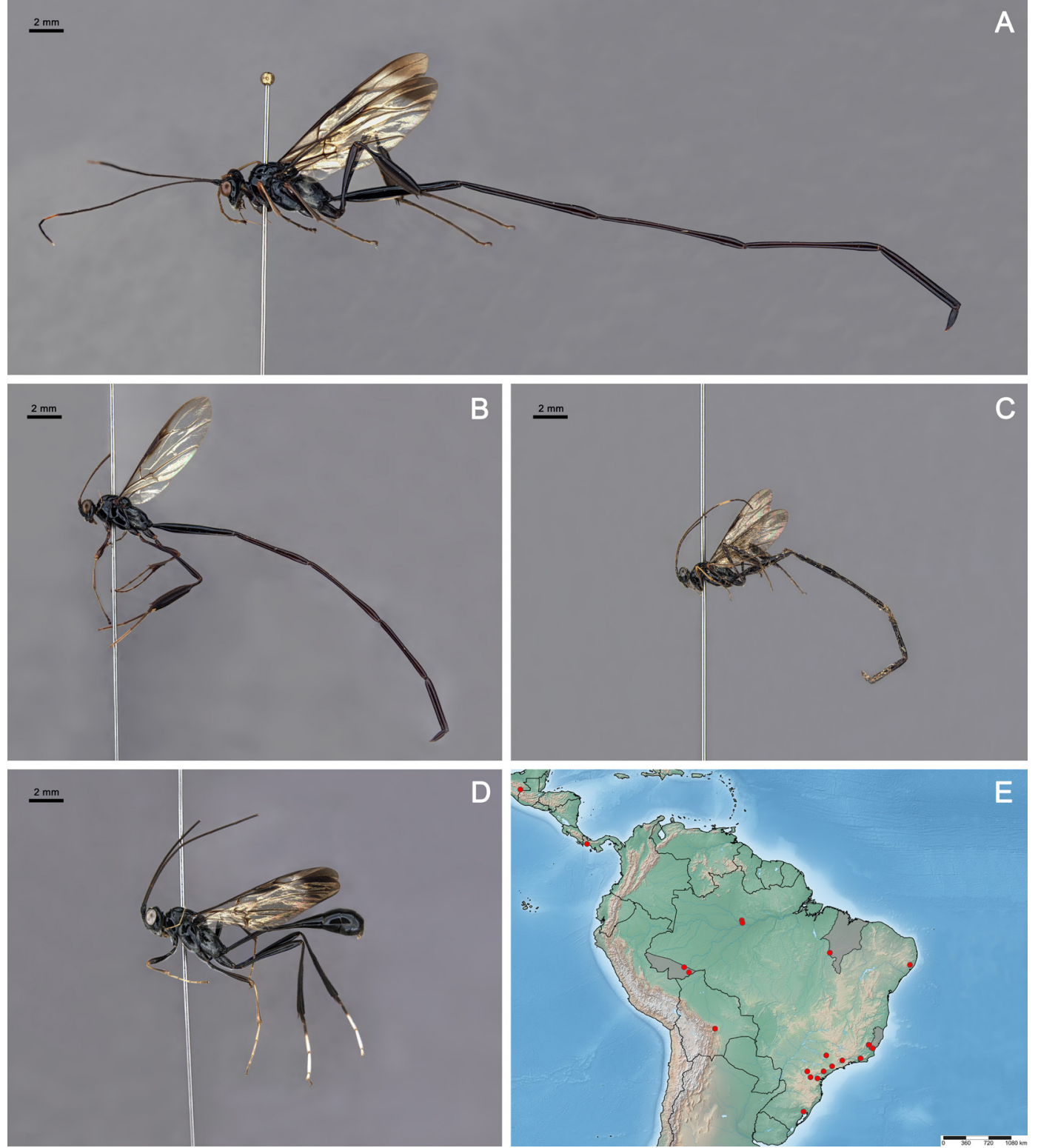

Figure 1. Pelecinus polyturator (Drury, 1773), habitus lateral. A. Female (State of Amazonas, Brazil). B. Female (State of Minas Gerais, Brazil). C. Female (State of Maranhão, Brazil). D. Male (State of Acre, Brazil). E. Distribution map (red dots = specimens studied; gray area = new state records).

\section{Authors' Contributions}

A.F.A.S., A.C.N., M.T.T. and D.R.R.F. identified the material and wrote the manuscript. All authors have discussed the results and contributed to its final version.

\section{Literature Cited}

Brues, C.T. (1928) A note on the genus Pelecinus. Psyche, 35: 205-209.

Drury, D. (1773) Illustrations of Natural History, vol. 2. London: B. White. 
Fernandes, D.R.R., Alves F.P., Shimbori, E.M., Lara, R.I.R., Silva Junior, J.C. \& Perioto, N.W. (2017) New distribution records of Sclerogibbidae (Hymenoptera: Chrysidoidea) in Brazil. EntomoBrasilis, 10: 33-36. https: / doi.org/10.12741/ ebrasilis.v10i1.658

Johnson, N.F. \& Musetti, L. (1999) Revision of the proctotrupoid genus Pelecinus Latreille (Hymenoptera: Pelecinidae). Journal of Natural History, 33: 1513-1543.

Lara, R.I.R. \& Perioto, N.W. (2014) Seasonality of Pelecinus polyturator (Drury) (Hymenoptera, Pelecinidae) in the Atlantic Rainforest of São Paulo State, Brazil. Revista Brasileira de Entomologia, 58: 63-65. https: / / doi.org/10.1590 / S0085-56262014000100010

Lara, R.I.R. (2020) Pelecinidae in Catálogo Taxonômico da Fauna do Brasil. PNUD. http:// fauna.jbrj.gov.br/fauna/faunadobrasil/ 90435 (accessed march 2020)

Lim, K.P., Yule, W.N. \& Stewart, R.K. (1980) A note on Pelecinus polyturator (Hymenoptera: Pelecinidae), a parasite of Phyllophaga anxia (Coleoptera: Scarabaeidae). The Canadian Entomologist, 112(2): 219-220.

Liu, C., Shih, C. \& Ren, D. (2009) The earliest fossil record of the wasp subfamily Pelecinidae (Hymenoptera: Proctotrupoidea: Pelecinidae) from the Yixian formation of China. Zootaxa, 2080(1): 47-54. https: / / doi.org/10.11646/ zootaxa.2080.1.4

Lucena, D.A.A., Santos Neto, P.E., Zanella, F.C.V., Alves, F.P., Trindade, O.S.N. \& Silva Junior, J.C. (2012) Chrysididae diversity (Hymenoptera) in caatinga vegetation in Jequié, Bahia state, Northeastern Brazil. Magistra, 24: 215-220.

Masner, L. (2006) Family Pelecinidae. In: Hanson, PE \& ID Gauld. Hymenoptera de La Región Neotropical. Memoirs of the American Entomological Institute, 77: 239-241.

Mason, W.R.M. (1984) Structure and movement of the abdomen of female Pelecinus polyturator (Hymenoptera: Pelecinidae). The Canadian Entomologist, 116(3): 419-426.

Perioto, N.W., Lara, R.I.R., Fernandes, D.R.R., De Bortoli, C.P., Salas, C., Crosariol Netto, J., Perez, L.A., Trevisan, M., Kubota, M.M., Pereira, N.A., Gil, O.J.A., Santos, R.F., Jorge, S.J. \& Laurentis, V.L. (2016) Monomachus (Hymenoptera, Monomachidae) from Atlantic rainforests in São Paulo State, Brazil. Revista Colombiana de Entomología, 42: 171175. https: / / doi.org/10.25100/ socolen.v42i2.6688

Shih, C.K., Liu, C.X. \& Ren, D. (2009) The earliest fossil record of Pelecinid wasps (Insecta: Hymenoptera: Proctotrupoidea: Pelecinidae) from Inner Mongolia, China. Annals of the Entomological Society of America, 102(1): 20-38. https: / / doi.org/10.1603/008.102.0103

Shorthouse, D.P. (2010) SimpleMappr, an online tool to produce publication-quality point maps. www.simplemappr.net (accessed march 2020.

Versuti, D.R., Paz, C.C.P., Lara, R.I.R., Fernandes, D.R.R. \& Perioto, N.W. (2014) Comparative abundance and diversity of Dryininae (Hymenoptera, Dryinidae) in three savannah phytophysiognomies in southeastern Brazil, under three sampling methods. Revista Brasileira de Entomologia, 58: 273-279. https: / / doi.org/10.1590/S008556262014000300008 